\title{
Kontener Lukasa Moodyssona - garb brzydkiego ciała
}

\section{Rafat Syska}

Uniwersytet Jagelloński

\begin{abstract}
W artykule dokonano gruntownej analizy filmu "Kontener" (Container, 2006) Lukasa Moodyssona, portretującego wewnętrzny świat psychocielesnych doświadczeń transseksualisty. Analizę filmu poprzedzono opisaniem dwóch fundamentalnych dla filmu kontekstów: ewolucji twórczości Lukasa Moodyssona i przemian w sposobie pokazywania transwestytów i trans-seksualistów w historii kina, a zwłaszcza na gruncie tzw. New Queer Cinema.
\end{abstract}

Słowa kluczowe: film, ciało, transseksualizm, film artystyczny, narracja subiektywna

Tematyka transseksualizmu doczekała się w ostatnich latach przynajmniej kilkunastu interesujących realizacji filmowych - zarówno w kinie eksperymentalnym, środowiskowym i autorskim, jak również w mainstreamowych produkcjach z Europy i USA. Szkicową panoramę tego rodzaju filmów przedstawię poniżej, ale już na wstępie zaznaczę, że nieodzowny - z oczywistych względów - motyw cielesności, fizycznego niedopasowania i brzydoty ulegał w nich stałej i niezmiennej tabuizacji, prowadząc częściej do komediowych przerysowań i karykaturalnych reprezentacji. Na plan pierwszy wysuwały się w filmach o transseksualistach konteksty społeczne (związane np. z nietolerancją otoczenia), rodzinne (będące konsekwencją pogmatwanych losów protagonistów) czy melodramatyczne (gdzie kulminacyjnym scenami stawało się szokujące dla partnerów osób transgenderowych ujawnienie płciowej tożsamości bohaterów). Temat transseksualizmu łatwiej było bowiem zaakceptować w oswojonej konwencji kina społecznego, obyczajowego czy familijnego - a często też sensacyjnego i komedii o drag queens - niż w poważnych analizach o psychoseksualnych implikacjach cielesnej niedoskonałości, brzydoty i braku akceptacji.

Powyższa strategia bez wątpienia fałszuje obraz zagadnienia i łagodzi problem, który dla transseksualistów stanowi najczęściej kierat niełatwej codzienności: chętniej więc w tych filmach ciało zasłaniano, niż ujawniano z wszelkimi jego wadami i odmiennościami, raczej akcentowano piękno i atrakcyjność niż niezgrabność, szpetotę i rozczarowanie. Przeglądając kluczowe dla zagadnienia filmy można zauważyć, iż jeden z nich wyróżnia się formą realizacji, która podkreśla ciemne strony egzystencji transseksualisty: jego/jej tożsamościową udrękę, samotność, niezdolność realizacji celów, rozpacz, depresję i schizofreniczne migracje podmiotowości. Zapewne te doświadczenia nie są stałe i niezbywalne w życiu transseksualisty, ale i takie mogą być częścią jego/jej losu. Kontener (Container, 2006) Lukasa Moodyssona - bo o nim mowa - to jedno z najbardziej przejmujących dzieł o cielesności: brzydkiej i nieakceptowanej, dla której ucieczką stało się stworzenie własnego, subiektywnego i rozległego w transpozycjach świata, który przestrzennie ograniczony był czterema ścianami tytułowego kontenera. 
Wybrałem ten film nie tylko dlatego, że jest dziełem wybitnym, choć wymagającym odbiorczo, ale przede wszystkim ze względu na całkowite pomijanie go w jakichkolwiek publikacjach poświęconych transseksualizmowi. Nie wspomina o nim Małgorzata Radkiewicz w monografii Oblicza kina queer, w której jeden długi rozdział poświęcony jest tematyce transgenderowej (Radkiewicz 2014). Zapomina o nim Carolyn Kraus w ważnym eseju Transsexualism as Cinematic Metaphor w magazynie "CineAction" (Kraus 2009). Warto więc nadrobić ten brak, zwłaszcza że przedmiotem analizy jest dzieło skrzywdzone i zepchnięte w niepamięć.

\section{Katastrofizm Moodyssona}

Z jednej strony krytyczna recepcja Kontenera nie może dziwić. Forma, jaką Moodysson opracował dla potrzeb filmu, a o której napiszę więcej w dalszych partiach tekstu, lokuje ten film bliżej kina eksperymentalnego, nawiązującego stylistycznie do odkryć awangardy lat sześćdziesiątych XX wieku. Trudno w tym wypadku mówić o klasycznej fabule, następstwie zdarzeń, związkach przyczyny i skutku czy klasycznie pojętej introdukcji i puencie. Zamiast dialogów słyszymy cichy, monotonny monolog wewnętrzny, przywodzący na myśl strumień świadomości nastoletniej dziewczyny; zamiast dziania się pozostaje dominujące wrażenie niezmienności stanu wyjściowego, który co najwyżej moduluje się w rozlicznych transpozycjach - wewnętrznie dynamicznych, ale też kreujących wrażenie zamierania. To była zasadnicza przyczyna odrzucenia filmu przez publiczność (ranking dzieła na stronie www.imdb.com wynosi tylko 5,3), ale też zaskakująco jednorodnej krytyki recenzentów. I tak, Peter Bradshaw na łamach „The Guardian" pisał o "fantastycznie nudnej kolekcji ziarnistych, monochromatycznych obrazów" (Bradshaw, 2006), a Philip Concannon, entuzjasta Moodyssona, łkał: "Gdzie zniknął reżyser trzech najpiękniejszych i najbardziej poruszających filmów poprzedniej dekady i kim jest ten agresywny, pozbawiony taktu i czaru filmowiec?" - dodając: "[Kontener - dop. R.S.] to nihilistyczne i wstrętne doświadczenie, które wydaje się być wyłącznie pustą prowokacją" (Concannon 2006).

Nie było to jednak pierwsze niepowodzenie Moodyssona - wcześniej w równie ekstremalnym stylu powstała jego zimna satyra na szwedzkie mieszczaństwo Dziura w sercu (Ett hål i mitt Harta, 2004), którą Concannon krytykował jeszcze ostrzej. Niemniej Moodysson w poprzednich latach zdołał wypracować sobie pozycję jednego z najbardziej utalentowanych twórców kina szwedzkiego, a wielbiony przez publiczność i namaszczony przez samego Ingmara Bergmana na swego następcę zrealizował wysoko cenione: Fucking Amal (Fucking Amål, 1998) i Tylko razem (Tillsammans, 2000). Pierwszy z filmów przedstawiał historię lesbijskiego romansu dwóch nastolatek z prowincjonalnego miasteczka, które najpierw borykały się z własnymi skłonnościami, a potem z presją otoczenia ponoć tolerancyjnych Szwedów. Drugi stanowił pielgrzymkę do dzieciństwa reżysera i opowiadał o komunie hippisowskiej, w której grupka młodych mieszczuchów (już pod koniec lat siedemdziesiątych XX wieku, gdy w zasadzie zgasła energia kontrkultury) stara się podtrzymać mit wolności, buntu i swobody decydowania o sobie. Puenta obu dzieł była przewrotna i nieoczywista: konwenanse stanowiły dla bohaterów ciężar i przekształcały ludzi w zakładników kulturowych i komunikacyjnych obostrzeń, ale z drugiej strony - stanowiły też ważny egzystencjalnie fundament stabilizacji i bezpieczeństwa, o którym marzyli zwłaszcza najmłodsi bohaterowie jego filmów. 
Dorosłość u Moodyssona to w istocie kierat codzienności, to frustracje wynikłe z niespełnienia aspiracji i pokuta za błędy popełnione przed laty. Tymczasem dzieciństwo i młodość to jeszcze niewinność i idealizm, na każdym kroku degradowane przez starszych. Obraz takiej młodości przedstawia pierwszy katastroficzny film Moodyssona, Lilia 4-ever (2002), gdzie bohaterką jest nastoletnia dziewczyna z postsowieckiego blokowiska, która uciekając przed alkoholizmem, wyrodnymi rodzicami, potworną biedą, bezrobociem, nikczemnością i - chyba tym co najgorsze - marazmem, decyduje się na emigrację do Szwecji. Wyjeżdża niby do pracy, ale w rzeczywistości staje się seksualną niewolnicą sadystycznych przestępców. Pozbawiona paszportu, trzymana pod kluczem, staje się ofiarą wielokrotnych gwałtów dokonywanych przez anonimowych klientów. W finale, udręczonej bohaterce wyrastają anielskie skrzydła - chrześcijańska manifestacja męki ciała, które stają się tu piękną i poruszającą metaforą jej samobójstwa.

Dopiero po premierze Lilii 4-ever, wracając do pierwszych dwóch filmów Moodyssona, można było dostrzec, że komediowa fasada kina obyczajowego skrywała w jego wypadku bardziej subwersywne komunikaty. Wyrażały się one przez dekonstrukcję formy, awangardowe chwyty inscenizacyjne i nielinearną narrację. Jednak dopiero w kolejnych dziełach reżysera, odejście od założeń Dogmy (dostrzegalne w Fucking Amal i Tylko razem), prowadziło do ewolucji filmowej narracji i wykreowania mniej uporządkowanej poetyki, niewygodnej dla masowego widza i zmuszającej do większej aktywności odbiorczej. Odtąd częściej pojawiały się fabularne przeskoki, niejasne powiązania między scenami, konfudujące zależności na granicach narracji obiektywnej i subiektywnej. Na plan pierwszy wysunął się katastrofizm, pesymizm, smutek, degradacja ciała i psychiki, a także samotność bohaterów. Stąd akcent fabuł został przełożony z opisu stosunków społecznych na bardziej intymne, cielesne i osobiste przeżycia protagonisty - bliskie charakterrystycznemu dla współczesnego kina nurtowi art-hard core (Syska 2014). W każdym z filmów musiała pojawić się choćby szczypta transgresji: nienormatywne zachowania seksualne, eksperymenty, nietypowe romanse i psychoseksualna przemoc, które stanowiły o dynamice ludzkiej osobowości, ale też otaczającej bohaterów społeczności.

Nie mogło więc dziwić, że Moodysson, zmęczony konwencjonalnym stylem swych pierwszych filmów, zdecydował się na formę najskrajniej odmienną, ulokowaną z dala od mainstreamu, a znacznie bliżej kina eksploatacji i awangardy. Tak powstała wspomniana już Dziura w sercu, jeden z najbardziej ekstremalnych, "obrzydliwych” i brutalnych, ale też apokaliptycznych dzieł najnowszego kina. Moodysson opowiedział w nim o trójce Szwedów, którzy w jednym z mieszkań decydują się nakręcić "domowe porno", przekształcając spotkanie w alkoholową libację, spektakl niewybrednej konsumpcji dóbr i w końcu wydalania na siebie niestrawionych jeszcze produktów. Scena wymiotowania w usta jednej z bohaterek należy już do legendarnych whistorii art-house'owego kina eksploatacji, stanowiąc niewątpliwy cytat ze słynnego Słodkiego filmu (Sweet Movie, 1975) Dušana Makavejeva - dekadenckiego podsumowania czasów kontestacji. W Dziurze w sercu nośnikiem destrukcji znów byli dorośli, choć odpowiedzią młodych na ich demoralizację i degrengoladę był wyłącznie akt separacji i marazmu (nastoletni syn jednego z bohaterów, przebywając podczas całej orgii w sąsiednim pokoju, symbolicznie zakłada na uszy słuchawki, zakleja oczy i popada w odrętwienie). Znowu eksperymenty ze sferą seksualną przeprowadzane są przez dorosłych bohaterów; młodzi, choć bardziej predestynowani do doświadczeń z własnym ciałem, popadają w katatoniczną nieaktywność, marząc co najwyżej o mieszczańskiej stabilizacji i obyczajowej kontrrewolucji. 
Następny film w karierze Moodyssona, Kontener, stanowił w tym wypadku kolejny krok w stronę katastroficznych wizji samotności, (auto)destrukcji i beznadziei bohaterów. Podjęte wcześniej wątki uległy tylko intensyfikacji, a postać transseksualisty, tutaj: brzydkiego, zatrzaśniętego we własnym ciele i klaustrofobicznej przestrzeni, stanowiła nośnik manifestowanych już wcześniej tematów: dekompozycji seksualnej tożsamości, degradacji kulturowych kodów (zwłaszcza słowa i komunikacji werbalnej), odseparowania w niewielkich przestrzeniach, schizofrenicznych transmisji osobowości i niszczycielskiego wpływu celebryckiego show-biznesu. Wszystkie te aspekty wyszły na wierzch, stanowiąc ważne tło dla opowieści o transseksualnym protagoniście. Nie tylko jednak kontekst twórczości Moodyssona stanowi dla Konteneru ważną bazę interpretacji. Kluczowe jest również ulokowanie tego filmu w kontekście współczesnego kina transgenderowego, podejmującego tematykę transseksualizmu.

\section{Od cross-dressingu do transseksualizmu}

Z tą tematyką nie spotykaliśmy się w kinie zbyt często, a jeśli już, to postaci transseksualistów pojawiały się w epizodach filmów sensacyjnych jako groźni dla otoczenia psychopaci. Częściej gościli na ekranach - tym razem w komediach - transwestyci i drag queens, a farsowe wersje przebieranek pojawiały się już w czasach najwcześniejszego kina niemego.

Analizująca to zjawisko Carolyn Kraus wskazała, że dopiero w latach pięćdziesiątych dokonano wyłomu w sposobie pokazywania transwestytyzmu (wcześniej ograniczonego do scenicznych występów mężczyzn przebranych za kobiety, co bardziej utrwalało, niż burzyło konwencjonalne postrzeganie płci). Tymczasem we wspomnianej dekadzie pojawili się na ekranach kin już bardziej kłopotliwi dla widza zdziwaczali transwestyci, konfrontujący odbiorcę ze swoją niejasną tożsamością płciową i zmuszający do redefinicji ponoć stabilnych kategoryzacji. Nie niosło to jednak głębokich i stałych przewartościowań, bo - jak dodaje Kraus - "filmy te oferowały uspokajające i odbudowujące stereotypy wytłumaczenie niepokojącej sytuacji, a czyniły to przez sprowadzenie postaci transseksualistów do roli dziwaków i celu żartów" (Kraus 2009: 19).

Autorka wspomina, że prawdopodobną przyczyną pojawienia się tematyki transseksualnej była pierwsza operacja korekty płci, przeprowadzona w latach 1951-1952 na George'u (Christine) Jorgensen, szeroko komentowana przez media i wykorzystana przez kino. Już rok po tej operacji trafił na ekrany film o psychiatrze zajmującym się przypadkami pacjentów transgenderowych Glen czy Glenda (Glen or Glenda, 1953) w reżyserii legendarnego Eda Wooda. Można więc stwierdzić, że o wiele łatwiej było zaakceptować filmy z postaciami, które przebierały się tylko na chwilę - zwykle dla występu na scenie bądź ukrycia się przed zagrożeniem - niż wówczas, gdy w grę wchodziła motoryka psychoseksualnych fantazji bądź wręcz kliniczny transseksualizm (kino rezerwowało tego rodzaju role wyłącznie dla groźnych morderców i maniaków - jak Norman Bates w Psychozie [Psycho, 1960] Alfreda Hitchcocka).

Trudno jednak w tym miejscu nie wspomnieć o długiej serii filmów o cross-dressingu, zwłaszcza że akurat w niej polskie kino może poszczycić się jedną z pierwszych udanych realizacji. I tak na przykład film Czy Lucyna to dziewczyna? (1934) Juliusza Gardana, z Jadwigą Smosarską w tytułowej roli, opowiadał o kobiecie, która po powrocie ze studiów zagranicą, tylko w męskim przebraniu, jako 
Juliusz Kwiatkowski, może podjąć pracę w fabryce swego zbyt tradycjonalistycznego ojca. Podobny schemat pojawiał się w kilkunastu innych filmach. W podręcznikach historii kina zapisały się takie dzieła jak: Tootsie (1982) Sydneya Pollacka, gdzie przyczyną przebieranki było bezrobocie telewizyjnego aktora, Victor Victoria (Victor/Victoria, 1982) Blake'a Edwardsa, opowiadający o środowisku piosenkarzy kabaretowych, i Sahara (1983) Andrew V. McLaglena, ulokowana wśród kierowców rajdowych. Ważnym dziełem była także Yentl (1983) Barbry Streisand, w którym sama reżyserka wcieliła się w rolę kobiety zmuszonej do przebrania się w męski strój w celu zdobycia wykształcenia, oraz Pani Doubtfire (Mrs. Doubtfire, 1993) Chrisa Columbusa, powszechnie znana komedia z Robinem Williamsem, w którym pragnący kontaktu z dziećmi ojciec przebiera się za ich niańkę i w ten sposób dostaje się do domu byłej żony. Najsłynniejszy pozostaje oczywiście nieśmiertelny film Billy'ego Wildera Pót żartem, pót serio (Some Like It Hot, 1959), gdzie przebieranka miała pozwolić na ucieczkę przed gangsterami, a po latach Rocky Horror Picture Show (1975) Jima Sharmana, w którym para młodych Amerykanów trafia w ręce zwariowanego transwestyty, doktora Frank-NFurtera, i jego zespołu tanecznego "Transylvanians".

W każdym z tych filmów cielesność była intrygująca, zabawna, może niezbyt doskonała, ale na pewno nieepatująca brzydotą czy obrzydliwością. Bohaterowie w przebraniach wprawdzie nie czuli się komfortowo, ale udając płeć przeciwną, realizowali konkretne zadania i zdawali sobie sprawę, że rychło będą mogli wrócić do poprzedniej tożsamości. Małgorzata Radkiewicz pisała: „Cross-dressing traktowany jest jako zabawny albo funkcjonalny tak długo, jak tylko zajmuje ograniczoną przestrzeń i czas, jak przystało na formę karnawalizacji. Źródłem komfortu i przyjemności odbioru jest przekonanie, że w finale płciowego spektaklu przebieraniec powróci do życia, jakie on albo ona prowadził czy prowadziła. Dopuszcza się jedynie, że jej lub jego »naturalna« podmiotowość oraz dalsza egzystencja będzie najprawdopodobniej uwzględniać ślad odgrywanej kobiecości lub męskości" (Radkiewicz 2014: 199).

Potwierdza to - o kilka lat późniejszy od Pani Doubtfire - film Nancy Meyers Czego pragna kobiety? (What Women Want, 2000), w którym męski szowinista, pracownik agencji reklamowej (Mel Gibson) najpierw (aby poznać potrzeby drugiej płci) zaczyna używać kobiecych kosmetyków, a potem w wyniku wypadku - otrzymuje dar (a raczej przekleństwo) słyszenia myśli swych partnerek. Komediowy charakter filmu nie powinien przesłonić zręcznej metafory zawartej w fabule: zainfekowanie nawet stuprocentowo męskiego mężczyzny kroplą kobiecości (przez kosmetyk, część garderoby, potrzebę poznawania codziennych trosk i udręk kobiet) nie może pozostać bez wpływu na charakter jego dalszego życia, naznaczonego czymś obcym i egzotycznym, ale zarazem pasjonującym i intrygującym. Radkiewicz pisze więc: „Akceptacja transseksualnych figur wynika z silnego przekonania, że płciowe przebranie jest jedynie tymczasową grą, a nie trwałą tożsamością, z jaką ma się do czynienia w przypadku transseksualizmu" (Radkiewicz 2014: 202) i konkluduje cytatem z Marjorie Garber: "Przebieranki mogą co najwyżej prowadzić do podważenia struktur kultury, destabilizować wzorce męskości i kobiecości, wprowadzać w obszar potencjalnej reorganizacji kategorii" (Graber 1997: 17).

Także John Philips, odwołując się w swoich analizach transgenderowości do słownika Bachtinowskich terminów, uznaje cross dressing za coś chwilowego i niezmuszającego do generalnego przeformułowania prymarnych dla płciowości definicji. Uznaje go za "rodzaj inwersji, czyli działania nie- 
zmieniającego binarnego układu, [podczas gdy] transseksualność to hybrydyzacja, łącząca się z ingerowaniem w zastany układ" (Radkiewicz 2014: 207-208). Transseksualizm - korzystnie waloryzowany - nie trafiał więc do kina mainstreamowego, a takie przypadki jak: Freak Orlando (1981) Ulrike Ottinger i w roku 13 petni (In einem Jahr mit 13 Monden, 1979) Rainera Wernera Fassbindera zdarzały się rzadko i wiązały się z przedsięwzięciami na polu kina autorskiego lub środowiskowego. Szczególnie ważny jest drugi z nich, bo stanowił być może pierwszą tak poważną próbę opisania codziennej udręki transseksualnego mężczyzny. Erwin (Volker Spengler) odchodzi od żony i dzieci, związuje się z sadystycznym i znęcającym się nad nim kochankiem, ubiera się w stroje kobiece i rozpoczyna starania o operację korekty płci. Już jako Elvira nie jest wcale bardziej szczęśliwy niż wcześniej. Rozczarowania miłosne idą w parze z nieakceptacją otoczenia, a problemy z wciąż nieuformowaną tożsamością potęgowane są przez niedoskonałości ciała: karykaturalnego, nieatrakcyjnego i zawieszonego między męskością a kobiecością.

Zmiana w sposobie portretowania transseksualizmu nastąpiła dopiero w latach 90. XX wieku wraz z pojawieniem się szerokiej fali filmów gejowskich, określonych przez B. Ruby Rich mianem New Queer Cinema ${ }^{1}$. Transseksualizm nie był w tym trendzie tematem wiodącym, ale najpierw była seria filmów traktujących go sensacyjnie: Gra pozorów (The Crying Game, 1993) Neila Jordana, Priscilla Królowa Pustyni (The Adventures of Priscilla, Queen of the Desert, 1994) Stephana Elliotta, Ślicznotki (To Wong Foo, Thanks for Everything, Julie Newmar, 1995) Beeban Kidron - a potem dzieła podejmujące zjawisko transseksualizmu bez jakichkolwiek ozdób gatunkowych: Nie czas na łzy (Boys Don't Cry, 1999) Kimberly Peirce i Transamerica (2005) Duncana Tuckera dokonały małej, choć nie rozwiniętej w nurt rewolucji.

W pierwszych trzech wymienionych wyżej filmach status transseksualizmu nie był jeszcze jasny, bo ich bohater(k)ami były gwiazdy show-biznesu, wykorzystujące swą transgenderowość dla celów performatywnych. To ścieżka znana kinu od najdawniejszych lat - nawet w historii polskiego filmu pojawiła się jej znakomita egzemplifikacja w postaci występu Eugeniusza Bodo w kobiecym przebraniu w komedii Piętro wyżej (1937) Leona Trystana. Drag queens to rzadko zniewieściali, delikatni i drobni mężczyźni, a częściej panowie w sile wieku, wysocy i szerocy w ramionach, co jeszcze silniej podkreślało (a nie rozmazywało) nieprzekraczalne granice płci. Kobieta w tych występach nie była więc wystarczająco "kobieca”, a mężczyzna "męski”, bo karykaturalne wzmocnienie płciowych różnic (przez kolorowe stroje, przerysowane gesty, krzykliwy makijaż i doprowadzoną do granic absurdu stereotypizację) miało wręcz podkreślać, że pełne scalenie się z drugą płcią nie jest możliwe. Zawsze pozostawała jakaś część poprzedniej płciowości, która w najlepszym przypadku bawiła (w kinie), choć częściej budziła ironiczny śmiech, opór, agresję i obrzydzenie (w życiu). A zatem takich bohaterów jak Dil z Gry pozorów, którzy w kobiecym stroju mogli bez kłopotu ukryć się w świecie kobiet, było niewielu (w filmie Jordana było wręcz odwrotnie: przebranie Dil w męski strój powodowało, że dopiero wtedy bohater zaczął się wyróżniać z tła).

1 Pojęcie to po raz pierwszy zostało przez nią użyte w artykule A Queer Sensation: New Gay Film w "Village Voice" 24 marca 1992. Wersję pełną, zatytułowaną już The New Queer Cinema można znaleźć m.in. w książce Harry Benshoff i Sean Griffin (red.) Queer Cinema. The Film Reader, Rutledge, New York, London 2004, s. 53-59. 
Dwa ostatnie filmy, Nie czas na łzy i Transamerica, wyrastały ponad inne, dlatego że opowiadały nie o scenicznych performerach, ale o zwykłych (choć transseksualnych) ludziach żyjących troskami przeciętnych mieszkańców Stanów Zjednoczonych. Oczywiście w obu scenariuszach wzmocniono aspekt sensacyjno-melodramatyczny, bo tylko w ten sposób można było nadać filmom atrakcyjniejszy dla widza (bo dystansujący go od codziennych kłopotów transseksualistów) charakter spektaklu. Tym niemniej, oba tym się odznaczyły, że wyszły poza oswojoną przez widza przestrzeń kabaretowej garderoby i sceny.

Nie czas na łzy opowiadał w tym kontekście autentyczną historię nastoletniego Teeny Brandona (nagrodzona za tę rolę Oscarem Hilary Swank), zgwałconego i zamordowanego przez rówieśników, gdy ci odkryli, że pod męskim przebraniem od dawna ukrywała się dziewczyna. Transamerica to z kolei kino drogi, opowieść o relacjach między nastoletnim synem a jego biologicznym ojcem, przechodzącym właśnie terapię zmiany płci. Te dwa filmy nie są jedynymi, w których transseksualizm stał się tematem wiodącym. Na zawsze Laurence (Laurence Anyways, 2012) Xaviera Dolana, Telenowela (En Soap, 2005) Pernille Fischer Christensen, XXY (2007) Lucíi Puento, Strella (2009) Panosa Koutrasa, a także liczne filmy Pedro Almodóvara, z Wszystko o mojej matce (Todo sobre mi Madre, 1999) i Skóra, w której żyję (La piel que habito, 2011) na czele - to tylko niektóre z nich. Cielesność, niedoskonałość fizyczna, przebrania i ukrywanie własnej tożsamości przed otoczeniem nadal stanowiły główny wątek scenariuszy, ale powolne przełożenie akcentu z performatywnej egzystencji drag queens na opis codziennych zmagań osób transseksualnych było już coraz bardziej zauważalne. Wciąż jednak melodramatyczny bądź sensacyjny charakter tych fabuł niwelował groźbę „patologicznej" identyfikacji widza i dopiero Kontener częściowo uniknął tych pułapek. W filmie tym Moodysson nie zderzał swego bohatera z problematyką ojcostwa, miłosnymi rozczarowaniami, nietolerancją otoczenia czy niezrozumieniem rodziny, ale z samotnością i depresją. Transseksualizm u Moodyssona to przede wszystkim odosobnienie i izolacja, których ciążącym wymiarem jest tożsamościowe podwojenie, bycie inną osobą w lustrze i inną wewnątrz siebie. Być może ta właśnie refleksja przyczyniła się do odrzucenia filmu, zbyt pesymistycznego i narzucającego pozbawioną nadziei puentę.

\section{Migracje podmiotu}

Pierwsze kłopoty krytyka filmowego pojawiają się już na etapie prób streszczenia fabuły Kontenera. Z niekoherentnej formy, stanowiącej niespójny strumień obrazów i cichego monologu, wyłania się opowieść o około trzydziestoletnim mężczyźnie (Peter Lorentzon), otyłym, nieatrakcyjnym fizycznie i samotnie żyjącym w niewielkim mieszkaniu. Wewnętrzny głos, należący do młodej dziewczyny, w pewnej chwili (ale nie na samym początku) wyjawia, że mamy do czynienia z osobą transseksualną, piękną kobietą zatrzaśniętą w ciele brzydkiego mężczyzny. Informacja ta nie dociera do nas w pierwszych scenach filmu, bo zastosowana przez Moodyssona struktura narracyjna pozbawiona jest charakterystycznych dla klasycznej fabuły etapów rozwoju zdarzeń - z introdukcją, rozwinięciem, perypetiami bohaterów, punktem kulminacyjnym i epilogiem. Słowa, które racjonalizują i lokują czasoprzestrzennie obserwowaną sytuację, musimy wyłapywać z chaosu setek innych, niepowiązanych ze sobą stwierdzeń wygłaszanych tą samą, pozbawioną ekspresji intonacją głosu. 
Bohatera określa więc nie tylko transseksualizm, samotność i przestrzenna izolacja, ale także patologiczne rozczepienie tożsamości, schizofreniczne rozproszenie podmiotowości i ciągłe migracje w inne osoby, wytworzone w jego chorej psychice. Stąd kłopoty widza z rozpoznaniem sytuacji wyjściowej i problemy z czasoprzestrzennym osadzeniem prezentowanych na ekranie zdarzeń. Moodysson obiera perspektywę pierwszoosobową, kreuje kunsztowny i niezmiennie subiektywny tryb opowiadania, w zasadzie nie proponując żadnych scen umożliwiających zdystansowanie się do bohatera, a zatem złapania "fabularnego azymutu”, zobiektywizowanej, zewnętrznej perspektywy poznawczej. Bohater/ka mieszka w pustym lokalu - tytułowym kontenerze - którym zapewne jest też samo nieakceptowane przez niego/nią ciało. Poszczególne obrazy nie są uspójnione przez zewnętrzny rytm: poranek, środek dnia, wieczór, noc; śniadanie, wyjście na zakupy, powrót do domu, obiad, szykowanie się do snu, wieczorną toaletę i oglądanie telewizji, bo Kontener to strumień niepowiązanych czasem i przestrzenią obrazów, niewynikających z siebie, choć tworzących wewnętrznie koherentną całość - puzzle składające się na osobowość schizofrenika.

W sferze wizualnej mamy więc bohatera przebierającego się w strój kobiecy, nakładającego niezdarnie tani makijaż lub krzykliwą perukę i wycinającego z kolorowych czasopism fotosy celebrytów. Wiele z jego zachowań łatwo zinterpretować jako transseksualne manifestacje uwięzienia we wrogim ciele: bohater pełza na czworakach po domu jak zwierz szukający wyjścia z klatki, wchodzi i wychodzi ze śpiwora jak z kokonu, a także chroni się przed czymś pod stołem albo kołdrą - jak przestraszone, zalęknione dziecko. Kilkukrotnie wracają obrazy siedzenia w bezruchu w masce przeciwgazowej, zakładania na głowę torebki foliowej, przyglądania się sobie w lustrze czy cierpliwego badania ścian - być może w celu znalezienia jakichś luk, szpar i dróg ucieczki.

Poruszające są w tym kontekście rzadkie sceny rozgrywające się na zewnątrz, owe przebłyski pamięci i reminiscencje chwil, gdy bohater opuścił swój kontener i trafił między ludzi, niezdarnie nawiązując kontakt z innymi i stając się obiektem kpin czy agresji. Tak było w krótkim epizodzie włączenia się do gry w piłkę nożną z chłopcami na przyszkolnym boisku, gdy bohater, udając ich rówieśnika, starał się wziąć udział w zabawie. Przeganiany przez uczniów, dopiero po kilku próbach zszedł niepocieszony z murawy. Podobnie było podczas jednej z imprez tanecznych, gdy bohater, najpewniej już pijany, usiłował poderwać jednego z gości. Stanowczo odsunięty na bok nie ponawiał próby i ostatecznie został pobity i poniżony przez resztę męskiego towarzystwa.

Przestrzeń, do której przynależy bohater, definiowana jest przez brud i rozkład. Stanowi ona wyrazistą reprezentację jego własnego ciała i psychiki - nieuformowanej, niekompletnej i pogrążonej w chaosie. Dlatego też mieszkanie nie przypomina przytulnego domu, a raczej więzienną celę lub, co bardziej przekonujące, lokal zastępczy, rodzaj dekoracji, zbitej z podrzędnej jakości paździerzy i zbudowanej tylko na chwilę. W mieszkaniu panuje ubóstwo, totalny nieład i zamęt. Niepościelone łóżko sąsiaduje z resztkami jedzenia na stole i porzuconymi na podłodze przedmiotami. Gdy w jednej ze scen bohater wychodzi na zewnątrz, to trafia na wysypisko śmieci, a wizualnym leit-motivem filmu staje się obraz kilkukrotnego wchodzenia do porzuconej przez ludzi budowli o industrialnobiurowym przeznaczeniu. W szarej przestrzeni na zewnątrz widzimy wyłącznie puste, brudne korytarze, windy towarowe, szpitalną izbę przyjęć i stacje metra; w środku domu - nieład przypadkowo zestawionych przedmiotów, pomiędzy którymi bohater przeciska się tak jak szaleniec usiłuje wydobyć się na powierzchnię z odmętów swej zdegradowanej psychiki. Antoni Kępiński w Schizofrenii 
pisał: „Poczucie nicości przenosi się czasem na własne ciało: narządy wewnętrzne przestają działać i gniją, ciało od środka zamienia się w próchno. Poczucie nicości może się przenieść na świat otaczający: staje się wypalonym pustkowiem" (Kępiński 2001: 110). Bohater/ka Kontenera monologuje więc o guzie rosnącym wewnątrz jego/jej ciała, o zdzieraniu skóry, rozkładzie ciała w grobie, a jednym tchem wymienia luźno związany ze sobą ciąg słów: „błony śluzowe, tkanka łączna, łożysko".

Im bardziej klaustrofobiczny, brzydki i niesatysfakcjonujący jest świat materialny protagonisty, tym bardziej poszerza się jego/jej świat wewnętrzny, nieznający żadnych granic i fizykalnych barier. Docieramy do niego przez dziewczęcy głos (użyczyła go gwiazda kina hollywoodzkiego Jena Malone), beznamiętnie i somnambulicznie opowiadający o alternatywnej rzeczywistości bohatera/ki. To w niej protagonist(k)a jest piękną, adorowaną przez mężczyzn dziewczyną, zdolną do romansu z Bradem Pittem i kariery u boku hollywoodzkich celebrytów. Jena peroruje więc o świecie showbiznesu: o zespole Spice Girls, głośnym samobójstwie gwiazdki porno Savannah, o raku piersi Kylie Minogue i losach Paris Hilton, Toma Cruise'a i Katie Holmes. Zlepek informacji z kolorowych czasopism wzbogaca o pseudofilozoficzne i społecznie zaangażowane komentarze i refleksje, scalając je z własnymi, intymnymi doświadczeniami.

Często wspomina też o awarii elektrowni atomowej w Czarnobylu, tak jakby z jasnej i atrakcyjnej wizualnie przestrzeni celebryckiego świata musiała wydobywać się mroczna strona bytu, ów pierwiastek katastrofizmu, rozkładu i nieodzownego zniszczenia. Nawet najbardziej heroiczne postawy urojeniowe zawierają w sobie kroplę destrukcji, upadku i zgnilizny, a wyrafinowane wizje alternatywnego życia, choć na pozór spełniają pokładane w nim nadzieje, ulegają stałej, odśrodkowej dekonstrukcji przez żywioł zniszczenia, owej immanentnej, substancjalnej sile antymaterii, nieopanowanej nawet przez osobowość oderwanego od świata schizofrenika.

To te przebłyski realnego świata pozwalają widzom ulokować czasoprzestrzenną sytuację fabularną filmu i złożyć w miarę spójną biografię bohatera. Z serii uwag, refleksji i reminiscencji dowiadujemy się więc, że już w wieku siedmiu lat bohatera wyzywano od "ciot", że długie godziny spędza on/ona w szpitalach, że został(a) odrzucony/a przez rodziców, że ktoś wykradł zdjęcia z jego/jej komórki i umieścił w Internecie, że matka zażywała valium, a on/a sam/a bierze środki antydepresyjne i dopingujące („Bułki z sezamem zanurzam w tonie kremu do rąk i kortyzonie” - mówi). Co więcej, w jednej z wypowiedzi słyszymy - wypowiedziane głosem Jeny Malone - że to do niej należy głos bohatera ("Nazywam się Jena Malone, jestem aktorką. To jest mój głos.”, „Nigdy nie byłam w Szwecji."). To z jednej strony akt samozwrotności medium, ujawnienie instancji nadawczej dzieła, ale z drugiej - co ważniejsze - dowód na moc zawłaszczenia: protagonista oddał swą osobowość Jenie Malone, wykorzystał jej głos, status gwiazdy i miejsce zamieszkania do stworzenia swej alternatywnej egzystencji, ale zarazem stał się jej zakładnikiem, mającym - w krótkich przebłyskach świadomości - wiedzę o prawdziwym statusie zaistniałej sytuacji. Protagonista mówi więc głosem Malone, ale mówi nim, że jest więźniem swego własnego ciała: transmisja i migracja za pośrednictwem Malone nie jest więc ani kompletna, ani w pełni możliwa, nie może też całkowicie wchłonąć tego, co nieakceptowane. Oddajmy raz jeszcze głos Antoniemu Kępińskiemu: „Człowiek [chory na schizofrenię - dop. R.S.] traci poczucie własnej rzeczywistości, co zwykle łączy się z poczuciem zmiany kształtów własnego ciała, gdyż własna rzeczywistość ma zawsze aspekt cielesny (depersonalizacja), 
lub traci poczucie rzeczywistości otaczającego świata, nabiera on aspektu makiety teatralnej (derealizacja)" (Kępiński 2001: 215).

Malone najczęściej więc monologuje. Mówi o tym, że Brad Pitt ma ją odwiedzić w Szwecji, wspomina o Leonidzie Breżniewie i Czarnobylu, będącym - jak jej ciało - okrytym grubą warstwą betonu i ołowiu sarkofagiem zniszczenia. Często łączy ze sobą słowa, frazy lub obserwacje mające ścisły, choć zawarty w mniej lub bardziej odległych symbolach, związek z jej osobistą sytuacją. Ale w niektórych fragmentach filmu kieruje pytania do swego wnętrza (a może lepiej powiedzieć zewnętrznej, brzydkiej, męskiej powłoki): „Gdybym była chłopcem, kochałabym się w Paris Hilton, ale jestem dziewczynką uwięzioną w męskim ciele", Wypuścisz mnie? Nie chcę być w tym ciele!”, "Czy odetniesz to wreszcie?”, "Sama mam to uciąć?!”. Aż wreszcie na końcu oskarża niewidocznych w kadrze lekarzy bądź rodziców/opiekunów: „Dlaczego dajecie mi te lekarstwa, jestem zdrowa, to wy jesteście chorzy". Monolog z rzadka zamienia się też w dialog: "Mogę się umówić z każdym.” "Nie, nie możesz!" - tak jakby transmisje i migracje podmiotu były wieloetapowe, niepozwalające na stałość i wykształcenie stabilnej struktury docelowej. Zamiast początku i puenty utrzymuje się wrażenie stałości i - jeśli mogę sobie pozwolić na oksymoron - wewnętrznie dynamicznej statyki stanu wyjściowego, podległego nie zmianom i ewolucji, ale delikatnym modulacjom i repetycjom. Rozwiązania konfliktu przecież nie można się spodziewać.

Z tego też powodu w sferze wizualnej postać głównego bohatera rozprasza się na jeszcze inną osobę: tajemniczą Chinkę (Mariha Åberg), będącą towarzyszką niektórych podróży, opiekunką, partnerem samotności, a przede wszystkim garbem (noszona na plecach przypomina plecak, uczepiony ciężar, krzyż dźwigany w prywatnej i bezgłośnej golgocie). Być może ten pomysł to prosta sugestia, że druga osoba, egzystująca jak „wewnętrzna narośl”, stanowi dosłowny, fizyczny ciężar, z jakim musi zmagać się bohater. Kępiński pisał: „Chory ma wrażenie, że druga osoba - może to być realna, bliska lub daleka, albo też wyimaginowana [...] wchodzi do niego” (Kępiński 2001: 208). „Cały świat próbuje dostać się do mojego wnętrza" - monologuje w jednym z fragmentów bohater/ka Kontenera.

Forma wybrana przed Moodyssona imponuje. Przebrnięcie przez jej narracyjne (wręcz matematyczne) wyrafinowanie jest - jak już wspomniałem - wyzwaniem dla niezaznajomionego z awangardowym kinem widza. Moodysson tworzy bowiem coś na kształt retro-awangardy², opierając inscenizację, montaż, ciąg wewnętrznych zależności między obrazami, a także obrazami i dźwiękami na doświadczeniach amerykańskich twórców filmu eksperymentalnego lat sześćdziesiątych XX wieku: zwłaszcza Stana Brakhage'a, a częściowo też Jonasa Mekasa (niektórzy krytycy dopatrują się odwołań do poetyki dadaizmu) (Heilman 2006). Stąd czarno-biała taśma, ręczna kamera, wyraźna ziarnistość obrazu, brak dźwięku diegetycznego, szybki, dynamiczny montaż przywodzący na myśl wideo-pamiętniki.

2 Tom Huddleston łączy Kontener z głośnym filmem Jonathana Caouette'a Tarnation (2003). Patrz: recenzja filmu zatytułowana Container zamieszczona blogu Not Coming to the Theater Near You na stronie internetowej: http://www.notcoming. com/reviews/container (dostęp: 10.06.2015). 
Tej niezwykłej struktury narracyjnej Moodysson używa do sportretowania samotnego, cichego, pustelniczego cierpienia transseksualisty, dodatkowo chorego na schizofrenię. Koncentruje się na jego odrzucanym i znienawidzonym ciele - brzydkim, dodatkowo deformowanym przez nieumiejętne nadawanie mu cech kobiecych; wzgardzonym i karanym w poruszających spektaklach upokorzeń i "mikrosamobójstw" (nakładanie torebki foliowej na głowę, pozwalanie innym na bicie i poniżanie). Już nieraz wspomniałem o dobranym przez reżysera tytule dzieła: kontener to nie tylko miejsce zdarzeń, to nie tylko też ciało będące więzieniem udręczonej nim kobiety, ale to też karcer psychiki bohatera/ki, rozbitej i umęczonej ciągłymi migracjami i transpozycjami.

Z tych właśnie powodów pozwoliłem sobie na szczególne wyróżnienie tego filmu. Obraz Moodyssona odróżnia się od innych wspomnianych wcześniej dzieł o transseksualizmie pod wieloma względami, ale przede wszystkim dlatego, że pokazuje ten problem nie jako proces zmierzający do - mniej lub bardziej satysfakcjonującej - puenty, ale jako ciężki, udręczający tok zdarzeń, który akurat w tym wypadku od początku skazany jest na klęskę, prowadząc do narastającej depresji, samotności i schizofrenii. W takich filmach jak Ślicznotki, Gra pozorów, a nawet Transamerica transseksualista jest gotowym konstruktem, niemal docelowym (cieleśnie) tworem ${ }^{3}$. W Kontenerze - podobnie jak psychika rozwarstwiła się na serie osobowości, tak ciało stało się ledwie manekinem, na który wkładane są chwilowe i niedocelowe kostiumy. To performens prywatny, pozbawiony sceny i widza. W jednym z fragmentów wewnętrznego monologu bohater(k)a mówi: „Pomyślałam, że wszystko, co wyśnię, spełni się. Odtąd nie odważyłam się pójść spać. Tyle jest nienawiści w mojej miłości".

\section{Bibliografia}

Bradshaw, Peter. 2006. Container. http://www.theguardian.com/film/movie/115277/container; dostęp: 10.06.2015.

Concannon, Philip. 2006. Container. http://www.philonfilm.net/2006/11/review-container.html; dostęp: 10.06.2015.

Lucas Moodysson, reż. 2006. Container. Szwecja, Memfis Film \& Television.

Garber, Marjorie. 1997. Vested Interest: Cross-dressing and Cultural Anxiety. London: Psychology Press.

Heilman, Jeremy. 2006. Container. http://www.moviemartyr.com/2006/container.htm; dostęp 10.06.2015.

Kępiński, Antoni. 2001. Schizofrenia. Kraków: Wydawnictwo Literackie.

\footnotetext{
${ }^{3}$ Filmy rzadko pokazują, jak ciężką pracą jest przygotowanie swego ciała do zaprezentowania go przypadkowym lub znajomym widzom. Zwykle jest ona sprowadzona do kilku konwencjonalnych działań przed lustrem w garderobie. Tymczasem dostosowanie męskiego ciała do kobiecego wyglądu (lub na odwrót) to zadanie trudne, wymagające rozlicznych eksperymentów i rzadko przynoszące satysfakcję. Jak zakryć ową pierwotną brzydotę i ułomność ciała? - filmy (zwłaszcza fabularne) nie podejmują tego tematu - lepiej uczyniła to choćby Mariette Pathy Allen w swym foto-eseju [w:] „Women \& Performance: A Journal of Feminist Theory" 20.3 (listopdad 2010), s. 267-283.
} 
Kraus, Carolyn. 2009. Screening the Borderland: Transsexualism as Cinematic Metaphor. W: "CineAction" 78.

Radkiewicz, Małgorzata. 2014. Oblicza kina queer. Kraków: Korporacja Ha!Art.

Syska, Rafał. 2014. Art-hard core. W: „EKRANy” 3-4, s. 26-34. 